\title{
A look behind the curtain: the editorial board
}

\author{
K. Brad Wray ${ }^{1}$ Luciano Boschiero
}

Published online: 18 October 2016

(C) Springer Science+Business Media Dordrecht 2016

An academic journal is a complex operation. We, the editors, rely on so many people who are almost invisible to our readers. Indeed, in some sense, their near invisibility is a sign of the proper functioning of the journal. Our readers, after all, are principally interested in reading the published reviews and seeing their own books reviewed in the pages of the journal.

But behind the smooth operation of the journal are staff members involved in the management and production of the journal based in the Netherlands. There are also the various people involved in the production and printing of the journal based in India. And we have a supportive and knowledgeable editorial board. Academic journal editorial boards serve a number of functions. Typically members for a journal editorial board are chosen from the most respected members of the research community. To some extent, their expertise constitutes the credibility of the journal. But at Metascience, our board members have a more active role. The aim of the journal is to ensure that the science studies community, that is, philosophers, historians, sociologists, anthropologists and other scholars studying science, are kept abreast of recent books in our far-ranging field or fields of study. With three issues a year, we publish reviews or symposia of approximately 80-90 books a year. It is exciting work.

We, the editors, each bring our own expertise to the journal, but we are hardly able to keep on top of all the recent publications in the various fields that look to our journal for guidance. Often we find ourselves relying on the expertise and knowledge of our editorial board. And they have proved to be useful resources when

\footnotetext{
K. Brad Wray

brad.wray@oswego.edu

Luciano Boschiero

1.boschiero@campion.edu.au

1 State University of New York, Oswego, NY, USA

2 Campion College, Sydney, NSW, Australia
} 
we need to find prospective reviewers for books in fields that lie far beyond our own areas of expertise. Over the last two years, we have discovered our own strengths in finding reviewers. But we have also become aware of blind spots. With an eye to ensuring that the journal does publish reviews of books in all the areas of study we purport to represent, we have expanded our editorial board, a process that will be ongoing.

We would like to take this opportunity to welcome two new members to the editorial board. In one respect, our two new board members need no introduction, as they will be familiar to many of our readers. They are accomplished scholars and widely recognized for their scholarly work and commitment to the profession. Laura Ruestche is a Professor of Philosophy at the University of Michigan. She specializes in philosophy of physics. She has already assisted us in finding reviewers for books in the more specialized and technical part of the philosophy of physics. Michael Lynch is a Professor of Science and Technology Studies at Cornell University. He has also provided insightful recommendations for reviewers for books on a range of topics in science studies. We would like to thank both Laura and Michael for their willingness to serve on the board and for their ongoing assistance in the operations of the journal. With this expansion to our board, the journal is now in an even better position to serve our readers. This is also an appropriate time to thank the longserving members of the board. Thank you all.

We can now close the curtains, and let you return to the reviews, the real reason that most of you have turned to the journal webpage or picked up a paper copy of the journal. There is much to relish in this issue, including two book symposia on recently published books by giants in the fields of history of science and philosophy of science. Many readers will be intrigued to read the symposia on Peter Harrison's The Territories of Science and Religion and Elliott Sober's Ockham's Razors: A User's Manual. 